\title{
Mycoplasma fermentans inhibits tumor necrosis factor $\alpha$-induced apoptosis in the human myelomonocytic U937 cell line
}

\author{
M Gerlic ${ }^{1}$, J Horowitz ${ }^{2}$ and S Horowitz ${ }^{\star, 1}$ \\ ${ }^{1}$ Faculty of Health Sciences, Department of Microbiology and Immunology, \\ Soroka University Medical Center, Ben-Gurion University, Beer-Sheva, Israel \\ 2 Department of Medicine A and Unit of Rheumatology, Ben-Gurion University, \\ Beer-Sheva, Israel \\ * Corresponding author: S Horowitz, Faculty of Health Sciences, Department of \\ Microbiology and Immunology, Soroka University Medical Center, Ben-Gurion \\ University, Beer-Sheva, Israel 84105. Tel: + 972 86477281; \\ Fax: + 972 86497556; E-mail: shulah@ bgumail.bgu.ac.il
}

Received 25.9.03; revised 11.4.04; accepted 03.5.04; published online 30.7.04 Edited by DW Nicholson

\begin{abstract}
Mycoplasma fermentans (M. fermentans) was shown to be involved in the alteration of several eukaryotic cell functions (i.e. cytokine production, gene expression), and was suggested as a causative agent in arthritic diseases involving impaired apoptosis. We investigated whether $M$. fermentans has a pathogenic potential by affecting tumor necrosis factor (TNF) $\alpha$ induced apoptosis in the human myelomonocytic U937 cell line. A significant reduction in the TNF $\alpha$-induced apoptosis ( $\sim 60 \%$ ) was demonstrated upon either infection with live $M$. fermentans or by stimulation with non-live $M$. fermentans. To investigate the mechanism of $M$. fermentans antiapoptotic effect, the reduction of mitochondrial transmembrane potential $\left(\Delta \Psi_{\mathrm{m}}\right)$ and the protease activity of caspase-8 were measured. In the infected cells, the reduction of $\Delta \Psi_{\mathrm{m}}$ was inhibited ( $\sim 75 \%$ ), and a $\sim 60 \%$ reduction of caspase-8 activity was measured. In conclusion, $M$. fermentans significantly inhibits TNF $\alpha$-induced apoptosis in U937 cells, and its effect is upstream of the mitochondria and upstream of caspase-8.

Cell Death and Differentiation (2004) 11, 1204-1212.

doi:10.1038/sj.cdd. 4401482

Published online 30 July 2004
\end{abstract}

Keywords: TNF $\alpha$-induced apoptosis; Mycoplasma fermentans; U937 cell line

Abbreviations: $\mathrm{AO}$, acridine orange; $\mathrm{BSA}$, bovine serum albumin; CFU, colony-forming units; $\mathrm{DiOC}_{6}(3), 3,3^{\prime}$-dihexyloxacarbocyanine iodide; EB, ethidium bromide; ELISA, enzymelinked immunosorbent assay; FACS, FACSCalibur flow cytometer; FADD, fas-associated death domain; FCS, fetal calf serum; FITC, fluorescein isothiocyanate; $\mathrm{mCiCCP}$, carbonyl cyanide $m$-chlorophenylhydrazone; MHC, major histocompatibility complex; $M$. fermentans, Mycoplasma fermentans; MOI, multiplicity of infection; NF- $\kappa$ B, nuclear factor $\kappa$ B; PBS, phosphate-buffered saline; PCR, polymerase chain reaction; PI, propidium iodide; PMSF, phenylmethylsulfonyl fluoride; PS, phosphatidylserine; RA, rheumatoid arthritis; TNFR, tumor necrosis factor receptor; TNF $\alpha$, tumor necrosis factor $\alpha ; \Delta \Psi_{m}$, mitochondrial transmembrane potential

\section{Introduction}

Mycoplasmas, the smallest self-replicating wall-less bacteria, exist as parasites in humans, and were shown to interact with various cells of the immune system, either by activation or suppression, resulting in alteration of cell functions. ${ }^{1} \mathrm{Myco}-$ plasma fermentans ( $M$. fermentans), a human pathogen, was shown to induce polyclonal activation of the immune cells, cytokine production, increased major histocompatibility complex (MHC) class II expression, increased cytotoxicity of $T$ cells and expression of oncogenes. ${ }^{2-6}$ In the last decade, there have been increasing numbers of publications implicating $M$. fermentans in the development of rheumatoid arthritis (RA), ${ }^{7-9}$ a disease characterized by impaired apoptosis. $^{8,10-12}$

Apoptosis is induced in two different pathways: the intrinsic and extrinsic pathways. tumor necrosis factor $\alpha$ (TNF $\alpha$ ), an inducer of the extrinsic pathway, crosslinks the TNF receptor (TNFR), which results in the activation of caspases, a class of cysteine proteases with specific functions in the execution of apoptosis. ${ }^{13}$ As a result of caspase activation, certain cellular substrates are cleaved and the cells undergo apoptosis. ${ }^{14}$

Several studies were published regarding mycoplasmas and apoptosis, but the results were contradictory. Mycoplasma proteins were shown to induce apoptosis in several cells, ${ }^{5,15}$ and it was shown that in Mycoplasma-contaminated cell cultures the internucleosomal DNA degradation is due to mycoplasmal endonuclease activity. ${ }^{16}$ Another study showed that mycoplasmal infections do not induce apoptosis, and even prevent it. ${ }^{17}$ In the present study, the indirect effect of mycoplasmal infection on apoptosis was investigated, by examining the effect of $M$. fermentans infection on apoptosis induced by TNF $\alpha$, in the human myelomonocytic U937 cell line, as an experimental model.

\section{Results}

Infection of U937 cells with $M$. fermentans did not induce apoptosis in the cells

To investigate whether $M$. fermentans infection of U937 cells induces direct apoptosis of the cells, the viability of the cells was examined at 24 and $48 \mathrm{~h}$ post infection. The FACSCalibur flow cytometer (FACS) analysis of Annexin-V-fluorescein isothiocyanate (FITC)- and propidium iodide (PI)-stained cells (Figure 1a) and cell cycle (Figure 2) demonstrated no difference in the percent of apoptotic cells between noninfected and infected cells. Thus, under the conditions used, 


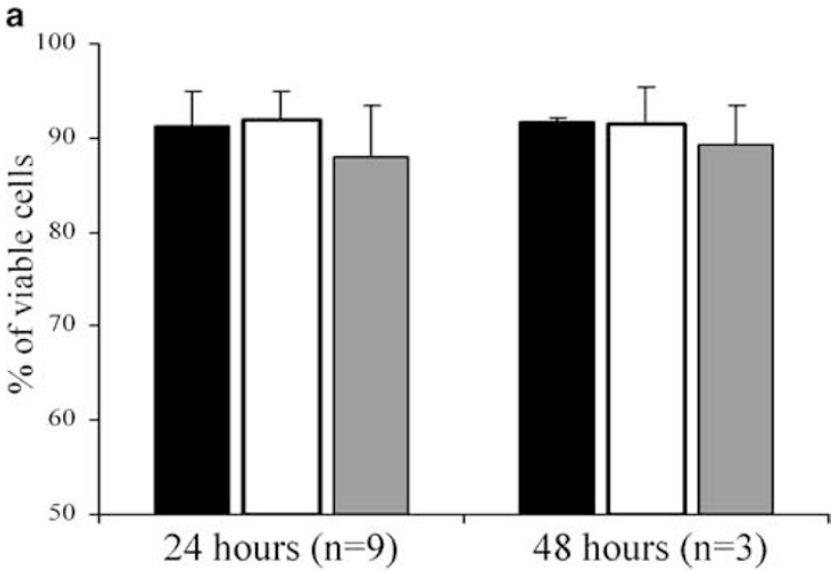

- Non-infected $\square$ Control-SP4 $-M$. fermentans infectd cells

b

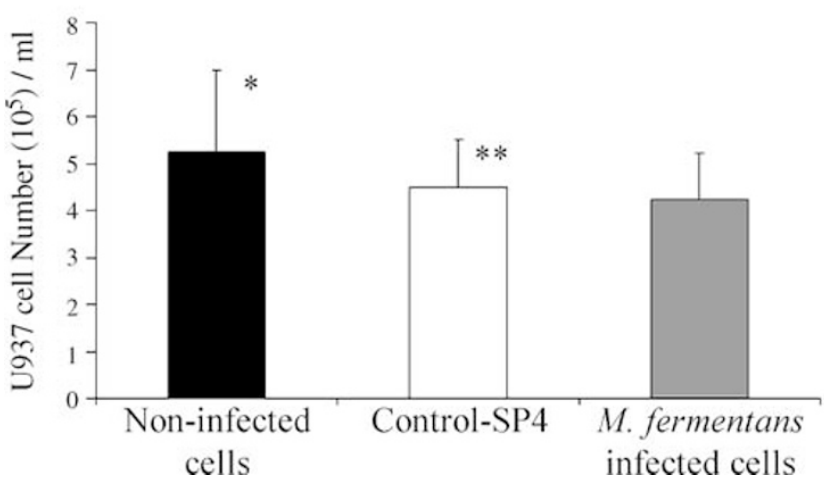

Figure 1 (a) Cell viability in M. fermentans-infected and noninfected U937 cells determined by Annexin-V-FITC-PI staining as analyzed by FACS. U937 cells were infected for $24 \mathrm{~h}(n=9)$ or $48 \mathrm{~h}(n=3)$ prior to cell staining. The mean percentage of live cells \pm standard deviation were as follows: $91 \pm 4 \%$ (at $24 \mathrm{~h}$ and $92+1 \%$ (at $48 \mathrm{~h}$ ), for noninfected cells (black); $92+3 \%$ (at $24 \mathrm{~h}$ ) and $91 \pm 4 \%$ (at $48 \mathrm{~h}$ ), for control culture treated with SP4 (M. fermentans medium) (white); and $88+6 \%$ (at $24 \mathrm{~h}$ ) and $89+4 \%$ (at $48 \mathrm{~h}$ ), for cells infected with $M$. fermentans (1000 CFU/cell) (gray). (b) Number of U937 cells in M. fermentansinfected and noninfected cultures, determined by trypan blue exclusion dye. U937 cells were infected for $24 \mathrm{~h}$ prior to cell staining (at a ratio of $1000 \mathrm{CFU} /$ cells). The mean percentage of cell number $\times 10^{5} / \mathrm{ml} \pm$ standard deviation was as follows: $5.2+1.7$ in noninfected cells; $4.5+1$ in SP4 control; $4.2+1$ in $M$. fermentans-infected cells (1000 CFU/cell). ${ }^{*} P<0.05,{ }^{* *} P$ - not significant

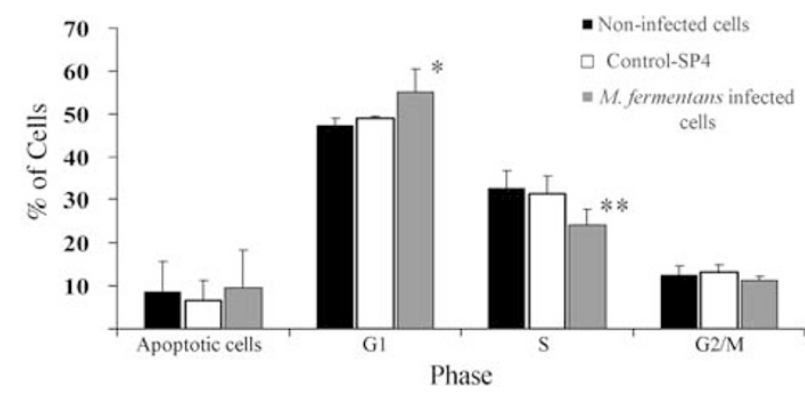

Figure 2 Cell cycle in M. fermentans-infected and noninfected U937 cells determined by PI staining as analyzed by FACS. U937 cells were infected with $M$. fermentans ( $1000 \mathrm{CFU} / \mathrm{cell}$ ) for $24 \mathrm{~h}$ prior to cell staining. The data are presented as the mean percentage \pm standard deviation of cells at different phases of the cell cycle, from three independent experiments. $M$. fermentans caused a $G_{1}$ arrest infection of U937 cells with $M$. fermentans did not induce apoptosis.

\section{Infection of U937 cells with M. fermentans causes a cell cycle arrest}

To investigate whether $M$. fermentans infection of U937 cells induces proliferation of the cells, we determined, at $24 \mathrm{~h}$ post infection, the number and viability of the cells by trypan blue exclusion dye, and analyzed the cell cycle. As seen in Figure 1a, there was no significant difference in percentage of viable cells between the infected and noninfected cultures. By cell cycle analysis, a small but statistically significant decrease in the percentage of cells in $\mathrm{S}$ phase was observed $(P<0.05$ for both controls), as well as a corresponding increase in the percentage of cells in $\mathrm{G}_{1}$ phase $(P<0.05$ for both controls) (Figure 2).

\section{Confocal microscopy of U937 cells infected with M. fermentans}

To determine the localization of $M$. fermentans with regard to U937 cells, we examined the cells by confocal microscopy. As seen in Figure 3 , at 12 and $24 \mathrm{~h}$ post infection, most of $M$. fermentans were localized at the surface of U937 cells. Some $M$. fermentans were observed inside the cells.

\section{TNF $\alpha$-induced apoptosis is reduced in U937 cells infected with $M$. fermentans}

Prior to investigating TNF $\alpha$-induced apoptosis, the levels of $\mathrm{TNF} \alpha$ secreted by U937 upon infection with $M$. fermentans were measured in the supernatants of the cultures, $24 \mathrm{~h}$ post infection. As shown in Figure 4, M. fermentans induced some secretion of $\mathrm{TNF} \alpha$, in a dose-response manner depending on the infection load $(P<0.05$ for an infection ratio of $1000 / 1)$, but the amount secreted even at the highest colony-forming units (CFU)/cell ratio (the ratio we used in all experiments) is negligible $(20 \mathrm{pg} / \mathrm{ml})$ as compared to the amount we used to induce apoptosis $(20 \mathrm{ng} / \mathrm{ml})$. Indeed, as shown in Figure 1a, the infected cells, after $24 \mathrm{~h}$, are not undergoing apoptosis.

The effect of $M$. fermentans on TNF $\alpha$-induced apoptosis $(20 \mathrm{ng} / \mathrm{ml})$ in U937 cells was determined $24 \mathrm{~h}$ post infection. The rationale for choosing $24 \mathrm{~h}$ after infection emerged from the results obtained both in the confocal microscopy and in electron microscopy (data not shown). The percentage of apoptotic cells was examined by two techniques: (1) Acridine orange $(\mathrm{AO})$-ethidium bromide $(\mathrm{EB})$ staining, which distinguishes between apoptotic and necrotic cells by the morphological changes in the nucleus (lack of DNA condensation in necrotic cells as opposed to apoptotic cells), ${ }^{18}$ was used to determine whether TNF $\alpha$ addition in our system induced apoptosis or necrosis. Firstly, TNF $\alpha$ addition induced apoptosis and not necrosis. Secondly, the apoptosis was reduced by $\sim 60 \%$ in $U 937$ cells infected with $M$. fermentans $(11.9 \pm 4.7 \%)$, in comparison to noninfected cells $(27.5 \pm 7.7 \%)$ and SP4-treated cells $(27.2 \pm 3.9 \%) ; P<0.05$ for both controls (Table 1); (2) A typical experiment of Annexin-V-FITC-PI staining is shown in Figure 5a. By this 
Non-infected cells
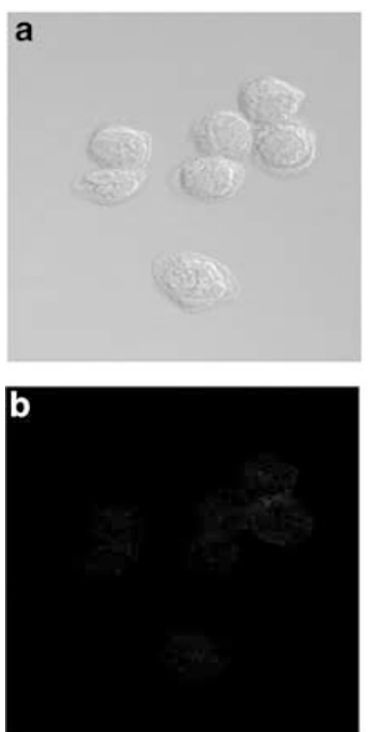

12 hours post infection
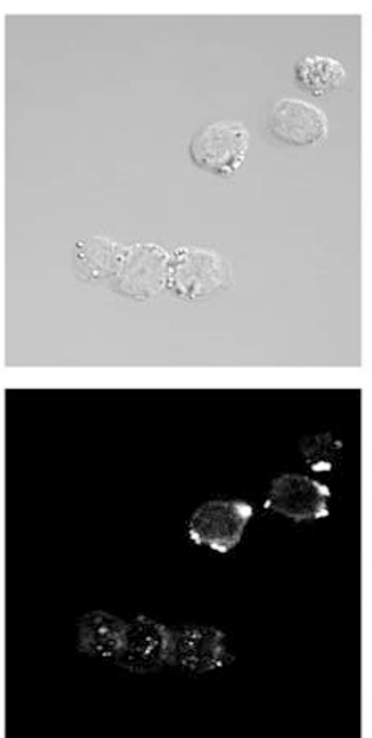

24 hours post infection
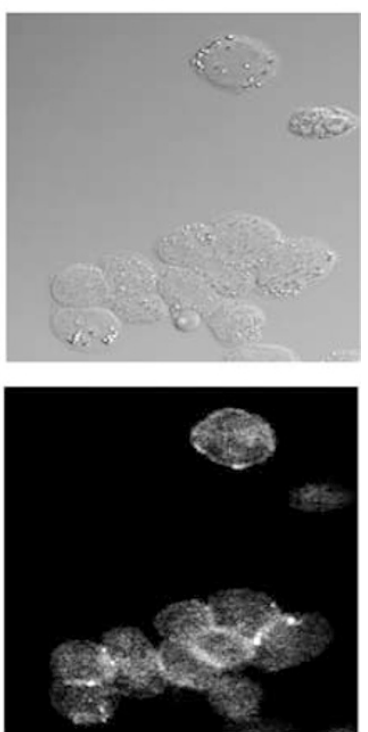

Figure 3 Confocal microscopy of $M$. fermentans-infected and noninfected U937 cells, at various infection times. Slides were prepared as described in Materials and methods. (a) Morphology of infected and noninfected cells. (b) The location of M. fermentans as detected with anti-M. fermentans antibodies

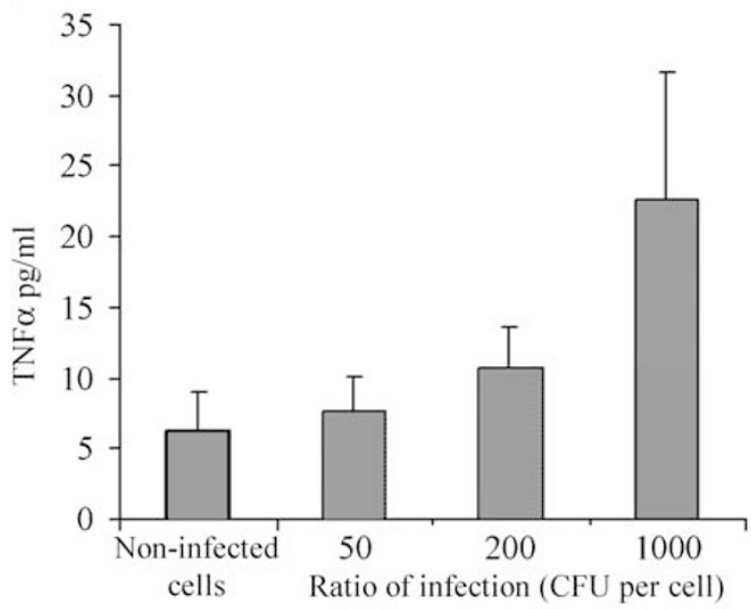

Figure 4 TNF $\alpha$ secretion by $M$. fermentans-infected and noninfected U937 cells, determined by ELISA. U937 cells were infected with M. fermentans for $24 \mathrm{~h}$ and TNF $\alpha$ in the supernatants was measured. Mean percentage \pm standard deviation of TNF $\alpha$ levels in the different cell cultures, from four separate experiments, are depicted

technique, necrotic and late apoptotic cells cannot be distinguished from each other, but, relying on the AO-EB technique, we concluded that the double-positive cells (for Annexin-V-FITC and PI) represent late apoptotic cells and not necrotic ones. The results, obtained in nine independent experiments, showed approximately $60 \%$ reduction in the percentage of apoptotic U937 cells infected with $M$. fermentans at a ratio of $1000 \mathrm{CFU} / \mathrm{cell}(6.5 \pm 2.8 \%)$, in comparison to noninfected cells $(19.8 \pm 4.3 \%)$ and SP4 control $(19.5 \pm 4.1 \%) ; P<0.01$ for both controls (Figure $5 \mathrm{~b})$. The specificity of the inhibitory effect of $M$. fermentans is demonstrated by the magnitude of inhibition, which was dependent on the ratio of CFU/cell (Figure 5b).

\section{Loss of mitochondrial inner transmembrane potential induced by TNF $\alpha$ is reduced in $U 937$ cells infected with $M$. fermentans}

In many apoptosis scenarios, including TNF $\alpha$-mediated apoptosis, the mitochondrial inner transmembrane potential $\left(\Delta \Psi_{\mathrm{m}}\right)$ collapses. ${ }^{19,20}$ To investigate whether the antiapoptotic effect of $M$. fermentans in TNF $\alpha$-induced apoptosis is upstream or downstream of the mitochondria, we measured the loss in $\Delta \Psi_{\mathrm{m}}$, induced by $\mathrm{TNF} \alpha(20 \mathrm{ng} / \mathrm{ml})$, in infected and noninfected cells. At $24 \mathrm{~h}$ post infection, the cultures were stimulated with TNF $\alpha(20 \mathrm{ng} / \mathrm{ml})$ for $2 \mathrm{~h}$, and each culture was stained with 3,3'-dihexyloxacarbocyanine iodide $\left(\mathrm{DiOC}_{6}(3)\right)$ and analyzed by FACS (a typical experiment is shown in Figure 6a).

In three independent experiments we found that, in U937 cells infected with $M$. fermentans, there was a fourfold reduction in $\Delta \Psi_{m}$ loss, $5.6 \pm 1.6 \%$ cells with low $\mathrm{DiOC}_{6}(3)$ fluorescence dye, compared to noninfected cells $(23.7 \pm 7.2 \%)$ and SP4-treated cells $(22.6 \pm 2.2 \%) ; P \leq 0.01$ for both controls (Figure 6b).

\section{Protease activity of caspase- 8 induced by TNF $\alpha$ is reduced in U937 cells infected with $M$. fermentans}

Caspase- 8 is at the apex of the caspase pathway and links death domain protein signaling (on TNF receptor) and caspase activation. ${ }^{14}$ To investigate whether the reduction of TNF $\alpha$-induced apoptosis in infected cells is upstream or downstream of caspase-8, we measured the protease activity of caspase- 8 induced by TNF $\alpha$, in infected and noninfected 
Table 1 Cell death induced by TNF $\alpha$ in M. fermentans-infected and noninfected U937 cells, as determined by fluorescence microscopy

\begin{tabular}{|c|c|c|c|c|c|}
\hline \multirow[b]{2}{*}{ Treatment } & \multirow[b]{2}{*}{$\%$ of live cells } & \multirow[b]{2}{*}{$\%$ of necrotic cells } & \multicolumn{3}{|c|}{$\%$ of apoptotic cells } \\
\hline & & & Early & Late & Total \\
\hline $\begin{array}{l}\text { Noninfected U937 } \\
\text { U937 treated with SP4 } \\
\text { U937 infected with } M \text {. fermentans }\end{array}$ & $\begin{array}{l}72.5 \pm 7.7 \\
72.8 \pm 3.9 \\
88.1 \pm 4.7\end{array}$ & $\begin{array}{l}<1 \\
<1 \\
<1\end{array}$ & $\begin{array}{r}18.3 \pm 4.4 \\
17.6 \pm 5.5 \\
9.0 \pm 3.1\end{array}$ & $\begin{array}{l}9.2 \pm 3.6 \\
9.6 \pm 3.9 \\
2.9 \pm 2.9\end{array}$ & $\begin{array}{l}27.5 \pm 7.7 \\
27.2 \pm 3.9 \\
11.9 \pm 4.7\end{array}$ \\
\hline
\end{tabular}

Values, quantified by random counting (in duplicate) of acridine orange-ethidium bromide-stained cells, are mean \pm standard deviation of data from three independent experiments. Percentages represent the different stages of cell death. The decrease in TNF $\alpha$-induced apoptosis, caused by $M$. fermentans, was $\sim 60 \%$ $(P<0.05$ for both controls as determined by ANOVA single factor)
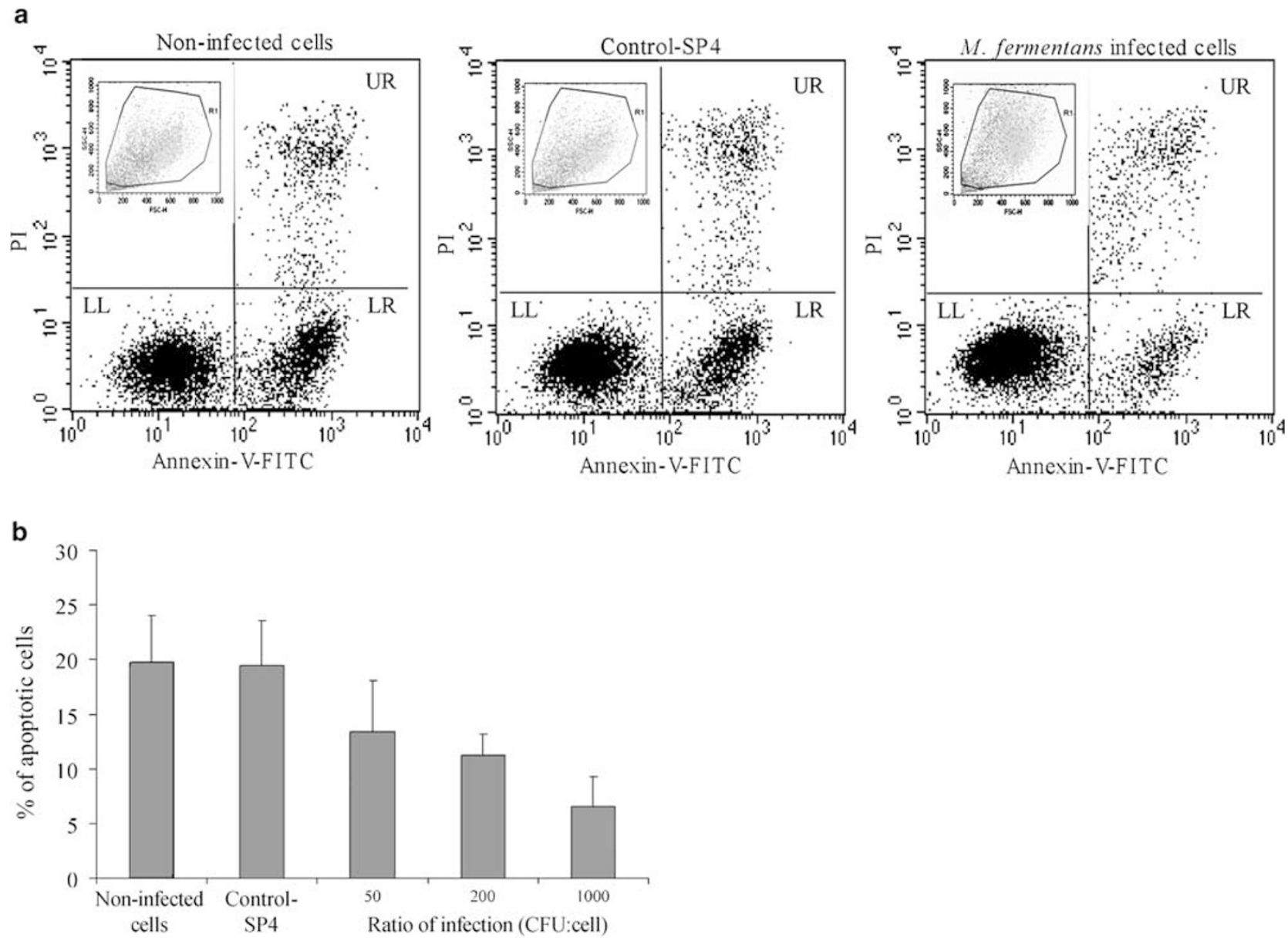

Figure 5 Measurement of TNF $\alpha$-induced apoptosis by Annexin-V-FITC-PI staining in M. fermentans-infected and noninfected U937 cells. (a) A representative experiment: Cells were infected for $24 \mathrm{~h}$ ( $1000 \mathrm{CFU} / \mathrm{cell})$, followed by addition of TNF $\alpha$ ( $20 \mathrm{ng} / \mathrm{ml})$ for $4 \mathrm{~h}$, stained with Annexin-V-FITC-PI and analyzed by FACS. Dot plots of forward and side scattered (with the gate used) are depicted on the upper-left corner of each treatment. Double negative staining represents live cells (LL), positive staining for Annexin-V-FITC and negative staining for PI represents early apoptotic stage (LR), and double-positive staining represents late apoptotic stage (UR). (b) Mean percentages of apoptotic cells \pm standard deviation were: $19.8 \pm 4.3 \%$ in noninfected cells, $19.5 \pm 4.1$ in SP4 control, and $13.4 \pm 4.7,11.2 \pm 2$ and $6.5 \pm 2.8 \%$ in M. fermentans-infected cells (50,200 and 1000 CFU/cell, respectively) $(P<0.05, P<0.01$ and $P<0.01$ in $M$. fermentans-infected cells $(50,200$ and 1000 CFU/cell, respectively) for both controls as determined by ANOVA single factor)

cells. At $24 \mathrm{~h}$ post infection, the cultures were stimulated with $\mathrm{TNF} \alpha(20 \mathrm{ng} / \mathrm{ml})$ for $4 \mathrm{~h}$ and cytosolic extracts were prepared. The assay for caspase- 8 activity was performed as described in Materials and Methods.

A $60 \%$ reduction in protease activity of caspase- 8 was measured in $M$. fermentans-infected U937 cells, compared to noninfected cells; $P<0.05$ (Figure 7 ).

\section{TNF $\alpha$-induced apoptosis is reduced in U937 cells treated with non-live $M$. fermentans}

To clarify whether the inhibitory effect of $M$. fermentans on TNF $\alpha$-induced apoptosis was exerted by live or non-live mycoplasma, cells were stimulated with sonicated $M$. fermentans prior to induction of apoptosis by $\operatorname{TNF} \alpha$. The 
a
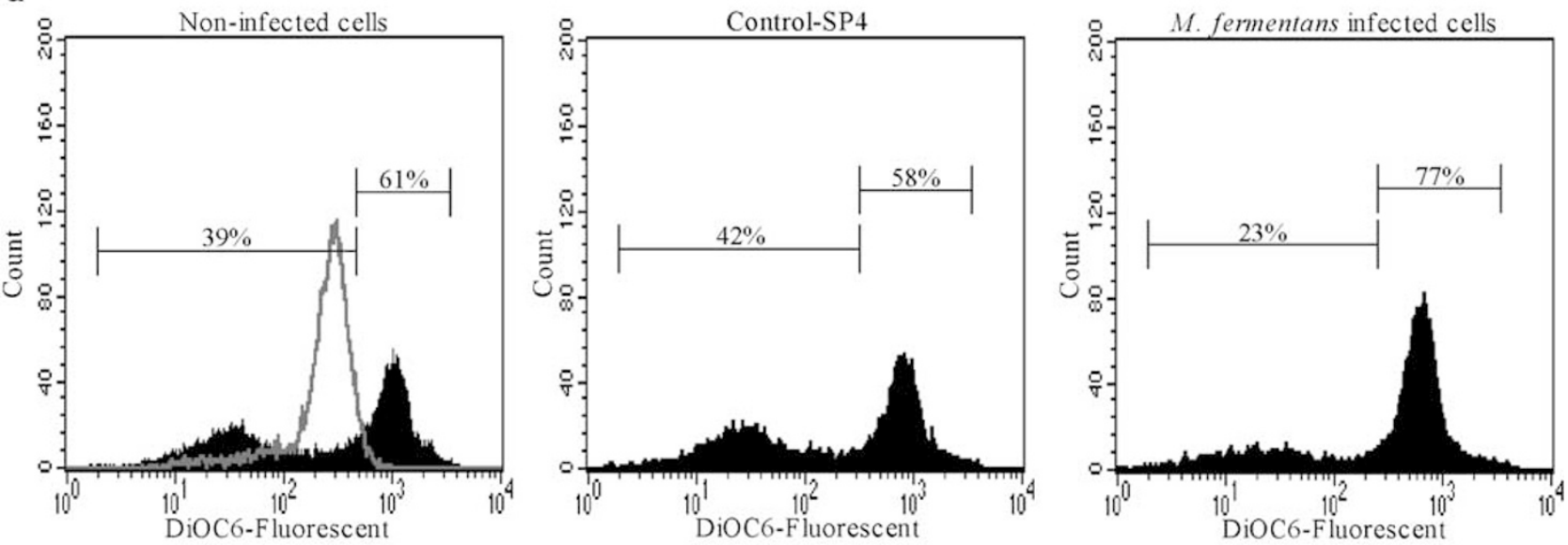

b

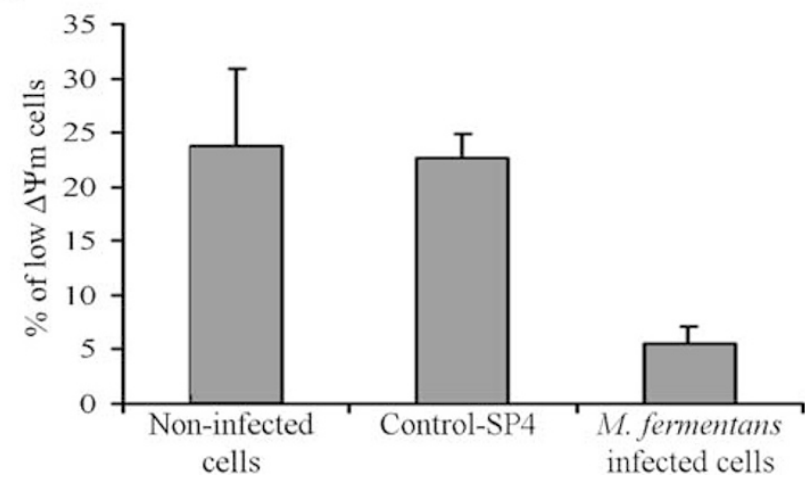

Figure 6 Determination of decrease in mitochondrial inner transmembrane potential induced by TNF $\alpha$ in $M$. fermentans-infected and noninfected U937 cells, by FACS of $\mathrm{DiOC}_{6}(3)$ fluorescence. (a) A representative experiment: Cells were infected for $24 \mathrm{~h}$, followed by addition of TNF $\alpha(20 \mathrm{ng} / \mathrm{ml})$ for $2 \mathrm{~h}$, stained with DiOC 6 (3) and analyzed by FACS. The percentage of cells with higher $\mathrm{DiOC}_{6}(3)$ staining (higher $\Delta \Psi_{\mathrm{m}}$ ) is on the right of each histogram, while the percentage of cells with lower $\mathrm{DiOC}_{6}(3)$ staining (lower $\Delta \Psi_{\mathrm{m}}$ ) is on the left. The line in the control histogram represents the positive control (mCiCCP). (b) Mean percentages of low DiOC 6 ( 3 ) fluorescence dye \pm standard deviation $(n=3)$ were: $23.7 \pm 7.2 \%$ in noninfected cells, $22.6 \pm 2.2 \%$ in SP4 control and $5.6 \pm 1.6 \%$ in $M$. fermentans-infected cells (1000 CFU/cell) ( $P \leqslant 0.01$ for both controls, as determined by ANOVA single factor). Overall, a fourfold reduction of $\Delta \Psi_{\mathrm{m}}$ loss was measured in $M$. fermentans-infected U937 cells

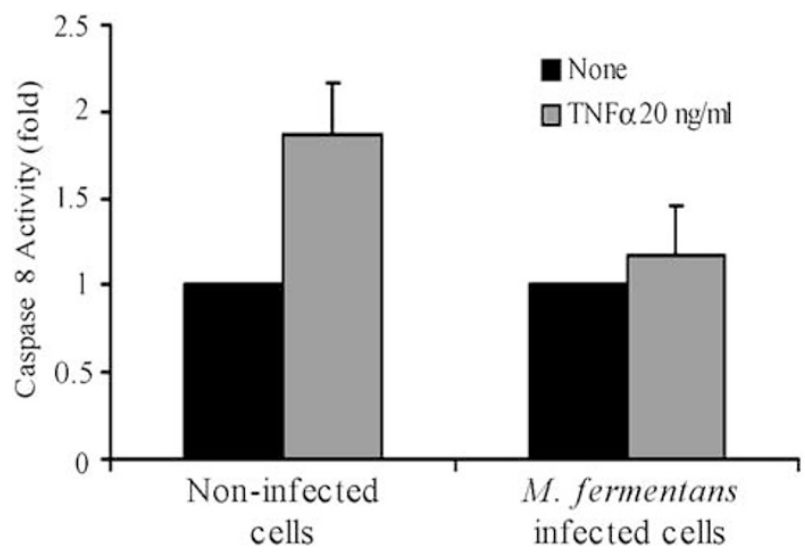

Figure 7 Protease activity of caspase-8 induced by TNF $\alpha$ in M. fermentansinfected and noninfected U937 cells. Cells were infected for $24 \mathrm{~h}$, followed by addition of TNF $\alpha(20 \mathrm{ng} / \mathrm{ml})$ for $4 \mathrm{~h}$, and cytosolic extracts were prepared. Mean percentages of caspase-8 activity \pm standard deviation $(n=3)$ were: $1.87 \pm 0.3$ fold in TNF $\alpha$-treated compared to untreated in noninfected cells, and $1.17+0.29$ fold in TNF $\alpha$-treated compared to untreated in M. fermentans-infected cells (1000 CFU/cell) $(P<0.05$ as determined by ANOVA single factor). The decrease in protease activity of caspase-8 caused by $M$. fermentans was $\sim 60 \%$ percentage of apoptotic cells was examined by Annexin- $\mathrm{V}$ FITC-PI staining. The results, obtained in four independent experiments, showed an $\sim 60 \%$ reduction of apoptotic cells in U937 cells stimulated with $40 \mu \mathrm{g} / \mathrm{ml}$ of sonicated $M$. fermentans $(9.6 \pm 3.8 \%)$, in comparison to noninfected cells $(23.7 \pm 4.7 \%)$ and phenylmethylsulfonyl fluoride (PMSF) control cells $(26.3 \pm 3.8 \%) ; \quad P<0.01$ for both controls (Figure 8). The inhibitory effect of sonicated $M$. fermentans on TNF $\alpha$-induced apoptosis was dose dependent (Figure 8).

\section{Discussion}

In this article, we report that infection of human myelomonocytic U937 cell line with $M$. fermentans does not cause a direct cell death but, rather, inhibits TNF $\alpha$-induced apoptosis. The block of apoptosis lies upstream of the mitochondria and upstream of caspase-8. It seems that the inhibitory effect of $M$. fermentans resides in constitutive components, since both live and non-live $M$. fermentans exert a similar effect.

$M$. fermentans has been shown to be both an extracellular and intracellular bacteria. ${ }^{7,21}$ We found, by confocal micro- 


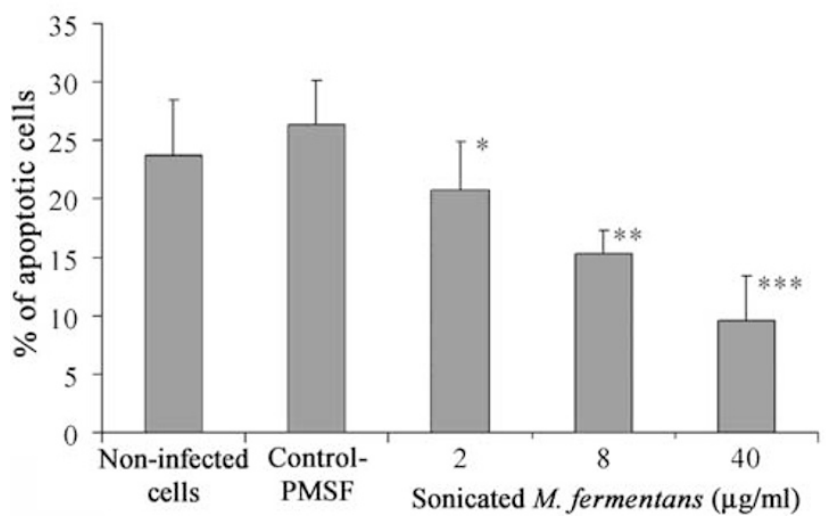

Figure 8 Measurement of TNF $\alpha$-induced apoptosis by Annexin-V-FITC-PI staining in U937 cells treated with non-live sonicated $M$. fermentans. Cells were treated with non-live sonicated $M$. fermentans for $24 \mathrm{~h}$, followed by addition of TNF $\alpha(20 \mathrm{ng} / \mathrm{ml})$ for $4 \mathrm{~h}$, stained with Annexin-V-FITC/PI and analyzed by FACS Mean percentages of apoptotic cells \pm standard deviation were: $23.7 \pm 4.7 \%$ in noninfected cells, $26.3 \pm 3.8$ in PMSF control, and $20.8 \pm 4.2 \%, 15.3 \pm 2$ and $9.6 \pm 3.8 \%$ in cells treated with the sonicated $M$. fermentans $(2,8$ and $40 \mu \mathrm{g} / \mathrm{m}$ respectively) $\left({ }^{\star} P<0.05,{ }^{* *} P<0.01\right.$ and ${ }^{* *} P<0.01$ for both controls as determined by ANOVA single factor)

scopy, that most $M$. fermentans cells were localized on the surface of U937 cells and that some of them became intracellular during the 8-24 $\mathrm{h}$ post infection (Figure 3 ). These findings suggest that $M$. fermentans might affect the cell either from the outer side of the membrane, or by stimulating the cell from its location within the cell.

The effect of mycoplasmas on apoptosis was previously examined in several studies. ${ }^{5,15-17}$ Most of the studies were engaged with the direct effect of Mycoplasma or mycoplasmal components on the apoptotic processes in infected cells. $M$. fermentans proteins were shown to induce apoptosis in various cell lines. ${ }^{5,15}$ In contrast, it was shown that mycoplasmal infections (under similar conditions, for example, multiplicity of infection (MOI)) do not induce apoptosis, and even prevent it. ${ }^{17}$ In the present study, we found that infection of U937 cells with $M$. fermentans for 24 or $48 \mathrm{~h}$ did not induce apoptosis (Figures 1a and 2), and induced an incomplete arrest in the cell cycle at $\mathrm{G}_{1}$ (Figure 2), as was previously reported. ${ }^{6}$ The contradiction between the studies might be explained by the fact that non-live mycoplasmal derivatives were used when apoptosis was demonstrated, ${ }^{5,15}$ whereas, when live mycoplasmas were employed, apoptosis was not induced. ${ }^{17}$ In another study, it was reported that Mycoplasma contamination of astrocytes (using similar MOI) could cause apoptosis, as a result of choline depletion in the medium, due to the mycoplasmal nutritional requirements rather than a direct effect of Mycoplasma on the cells. ${ }^{22}$ Indeed, Rawadi et $a \bar{F}$ reported that the proapoptotic effect resides exclusively in the nonlipid protein fraction of $M$. fermentans and not in the lipid fraction; this might explain why live Mycoplasma (enveloped only by a lipid membrane) do not cause apoptosis or cell death. In our system, U937 cells were infected with live $M$. fermentans. Although we were not able to grow $M$. fermentans from the culture $24 \mathrm{~h}$ post infection (data not shown), it is likely that U937 cells came into contact with $M$. fermentans membrane lipoproteins. This might explain why, in our system, there was no apoptosis during the 24 or $48 \mathrm{~h}$ post infection.

To our knowledge, this is the first report presenting the ability of Mycoplasma to inhibit TNF $\alpha$-induced apoptosis. Only a few papers have been published regarding inhibition of TNF $\alpha$-induced apoptosis by Chlamydia pneumonia ${ }^{23,24}$ and Hepatitis C Virus. ${ }^{25}$ These support the hypothesis ${ }^{26}$ that parasite bacteria might use a mechanism to prevent host cell apoptosis, in order to promote their survival and replication.

In TNF $\alpha$-mediated apoptosis, the $\Delta \Psi_{\mathrm{m}}$ collapses, resulting in cytochrome $c$ release. ${ }^{19,20}$ A fourfold reduction in $\Delta \Psi_{m}$ loss was observed in infected cells as compared to noninfected cells (Figure 6). Therefore, we concluded that the effect of $M$. fermentans is upstream of the mitochondria. This result is similar to a recent observation regarding the effect of Chlamydia pneumoniae infection, ${ }^{23,24}$ which was reported to render epithelial and monocyte cell lines resistant to TNF $\alpha$ induced apoptosis, via blockage of mitochondrial cytochrome $c$ release.

It is well known that the $\mathrm{Bcl}-2$ protein family regulates the $\Delta \Psi_{\mathrm{m}}$ loss in apoptosis, ${ }^{27,28}$ but, as yet, we have no evidence that these proteins are upregulated or downregulated in our infected cells (data not shown).

Binding of TNF $\alpha$ to the TNFR1 causes fas-associated death domain (FADD) to bind the receptor. Procaspase- 8 binds the receptor-bound FADD, leading to its proteolytic activation. This, in turn, can lead to an apoptotic process via two branches, either directly by activation of caspase-3 (extrinsic), or by release of cytochrome $c$ from the mitochondria (intrinsic). ${ }^{13}$ By comparing caspase- 8 activity (induced by TNF $\alpha$ ) in infected and noninfected cells, we found that there was a $60 \%$ reduction of protease activity of caspase- 8 in infected cells, indicating that the inhibitory effect of $M$. fermentans on TNF $\alpha$-induced apoptosis is upstream of caspase-8 (Figure 7).

Our finding that $M$. fermentans inhibit TNF $\alpha$-induced apoptosis might be explained by the effect of $M$. fermentans on the transcription factor, nuclear factor $\kappa \mathrm{B}$ (NF- $\kappa \mathrm{B})$. NF- $\kappa \mathrm{B}$ activation is known to inhibit TNF $\alpha$-induced apoptosis via suppression of caspase-8 activation. ${ }^{29}$ It was previously reported that $M$. fermentans cause NF- $\kappa$ B activation in human monocytic cell line and murine macrophages. ${ }^{5,17,30}$ In a preliminary study, we found that, in our system, NF- $\kappa \mathrm{B}$ was translocated to the nucleus in $M$. fermentans-infected cells (data not shown).

Alternatively, since most of $M$. fermentans were associated with the U937 cell membrane (Figure 3), the notion that the antiapoptotic effect of $M$. fermentans is exerted via modulation of TNF receptors has surfaced. This is currently under investigation in our laboratory, and preliminary results indicate that there is no significant difference in TNFR1 expression between infected and noninfected cells (data not shown).

The inhibition of TNF $\alpha$-induced apoptosis was also evident when cells were stimulated by non-live $M$. fermentans, similar to the effect of infection with live M. fermentans (Figure 8). Although we infected cells with live $M$. fermentans, we cannot conclude whether the inhibition of TNF $\alpha$-induced apoptosis was due to live or non-live Mycoplasma, since live $M$. fermentans could not be cultivated after $24 \mathrm{~h}$. However, in 
preliminary experiments, when live $M$. fermentans were recovered from the culture, $2 \mathrm{~h}$ post infection, the antiapoptotic effect was already demonstrated (data not shown). These results suggest that both live and non-live $M$. fermentans exerted inhibition of the TNF $\alpha$-induced apoptosis.

In summary, the findings that $M$. fermentans causes a significant inhibition of TNF $\alpha$-induced apoptosis in U937 cells strengthen the hypothesis that $M$. fermentans might play a pathogenic role in the development of diseases characterized by impaired apoptosis. These findings also imply that the presence of mycoplasmas in various cell lines might be affecting the results of apoptosis research. ${ }^{31}$

\section{Materials and Methods}

\section{Reagents and antibodies}

Recombinant TNF $\alpha$ and TNF $\alpha$ determination kit (enzyme-linked immunosorbent assay (ELISA)) were purchased from R\&D Systems, Inc. (Minneapolis, MN, USA). Annexin-V-FITC and PI were purchased from Bender MedSystems (Vienna, Austria). The 3,3'-dihexyloxacarbocyanine iodide $\left(\mathrm{DiOC}_{6}(3)\right)$ and goat-anti-mouse conjugated to Alexa-Fluor 488 were purchased from Molecular Probes, Inc. (Junction City, OR, USA). Carbonyl cyanide $m$-chlorophenylhydrazone (mCiCCP), EB, AO and PMSF were purchased from Sigma Chemical Co. (St. Louis, MO, USA). The caspase-8 Assay Kit was obtained from Calbiochem (Nottingham, UK). Cell culture media and supplements were purchased from Biological Industries Ltd (Beit Haemek, Israel).

\section{Mycoplasma culture and mycoplasmal non-live preparation}

M. fermentans K7 (originally obtained from JG Tully (National Institute of Allergy and Infectious Diseases, National Institutes of Health, Bethesda, MD, USA)) was cultured in SP4 broth containing $8.5 \%$ fetal calf serum (FCS). ${ }^{32,33}$ Aliquots $\left(1 \mathrm{ml}\right.$ ) (containing $4 \times 10^{8} \mathrm{CFU}$ ) were frozen at $-70^{\circ} \mathrm{C}$. For each experiment, one aliquot was thawed and cultivated in SP4 broth first, at a dilution of $1 / 10$ for $24 \mathrm{~h}\left(37^{\circ} \mathrm{C}\right)$, and then stepped up at a $1 / 50$ dilution for another $24 \mathrm{~h}$, when log phase was observed. $M$. fermentans was quantified by counting of CFU on SP4 agar plates. ${ }^{32,33}$

Non-live Mycoplasmas were prepared as follows: M. fermentans was cultivated as above and the $500 \mathrm{ml}$ culture was pelleted $(13000 \times \mathrm{g}$, $30 \mathrm{~min}$ at $4^{\circ} \mathrm{C}$ ), and washed twice with phosphate-buffered saline (PBS). The pellet was then resuspended in $2 \mathrm{ml}$ of PBS. CFU/ml was determined and then stored at $-70^{\circ} \mathrm{C}$ for further experiments. Frozen pellets of $M$. fermentans were thawed and sonicated at $4{ }^{\circ} \mathrm{C}$ for $4 \times 30 \mathrm{~s}$ at $80 \%$ power (50\% duty cycle; Heat Systems Ultrasonics, Inc.) in the presence of the protease inhibitor PMSF $\left(10^{-4} \mathrm{M}\right)$. These conditions of sonication resulted in a non-live mycoplasmal preparation (no growth was observed in repeated culturing procedures). Protein concentration of sonicated $M$. fermentans was determined by using the Bio-Rad protein assay kit (Richmond, CA, USA). An amount of $1 \times 10^{8} \mathrm{CFU}$ corresponds to $10 \mu \mathrm{g}$ of mycoplasmal proteins.

\section{Cell culture}

The human myelomonocytic U937 cell line was cultivated at $37^{\circ} \mathrm{C}$ and $5 \%$ $\mathrm{CO}_{2}$, in RPMI 1640 culture medium containing 10\% FCS, $1 \%$ HEPES, $1 \%$ penicillin-streptomycin and $1 \%$ glutamine. The cell line was tested every 4 weeks by a polymerase chain reaction (PCR)-based detection assay for M. fermentans contamination. ${ }^{9}$

\section{Stimulation of U937 cells with live M. fermentans or sonicated $M$. fermentans}

Prior to infection with live $M$. fermentans, Mycoplasmas (at a log phase) were washed once in PBS $\left(13000 \times g, 30 \mathrm{~min}\right.$ at $\left.4^{\circ} \mathrm{C}\right)$, and resuspended in RPMI 1640 medium containing 10\% FCS, 1\% HEPES, 1\% penicillinstreptomycin and $1 \%$ glutamine. Then, M. fermentans was added to U937 cells, pre-washed once with PBS $\left(500 \times g, 10 \mathrm{~min}\right.$ at $\left.4^{\circ} \mathrm{C}\right)$, and resuspended in a new culture medium at a final concentration of $2 \times 10^{5} \mathrm{cells} / \mathrm{ml}$. The ratio of Mycoplasmas/cell to be used was predetermined by a series of dose-response experiments, at various ratios (50/1, 200/1, 1000/1). A ratio of $1000 \mathrm{CFU/cell} \mathrm{was} \mathrm{chosen} \mathrm{since,} \mathrm{under}$ these conditions, the effect of $M$. fermentans on cells was more pronounced. The same procedure, with the same volume as in the $M$. fermentans culture, was performed with SP4 broth to be used as on the SP4 control. For experiments with non-live M. fermentans, the sonicated Mycoplasma (prepared as described above) was added to U937 $\left(2 \times 10^{5}\right.$ cells $/ \mathrm{ml}$ ) cells at concentrations of 2,8 and $40 \mu \mathrm{g} / \mathrm{ml}$. PMSF control is a noninfected cell culture with the addition of PMSF, at the same concentration as in the sonicated M. fermentans.

\section{Cell cycle analysis}

At $24 \mathrm{~h}$ post infection, U937 cultures were washed and fixed with $1 \mathrm{ml}$ of $70 \%$ cold ethanol. Cells were kept in the fixative for at least $24 \mathrm{~h}$ at $-20^{\circ} \mathrm{C}$. Followed by centrifugation and removal of the ethanol, pellets were resuspended in $900 \mu \mathrm{l}$ of a solution containing $0.1 \%$ Triton X-100 and RNase $(10 \mu \mathrm{g} / \mathrm{ml})$ in PBS. The cells were kept for $40 \mathrm{~min}$ at room temperature, and stained with $100 \mu \mathrm{l}$ of PBS containing $\mathrm{PI}(150 \mu \mathrm{g} / \mathrm{ml})$. After incubation on ice for $10 \mathrm{~min}$, the cells were analyzed by a FACS (Becton-Dickinson, Mansfield, MA, USA). The population of cells in each cell cycle phase was determined by using ModFit LT software (Becton Dickinson Immunocytometry Systems).

\section{Confocal microscopy}

U937 cells were infected with $M$. fermentans, as described above, for different time periods $(0,1,2,4,12$ and $24 \mathrm{~h})$. Each culture was fixed with $3.7 \%$ formaldehyde (in Eppendorf tubes) for $30 \mathrm{~min}$ at room temperature and washed twice with PBS. Cells were then permeabilized by $0.2 \%$ Triton $\mathrm{X}-100$ for $5 \mathrm{~min}$ at room temperature, washed twice with PBS, and blocked with $1 \%$ bovine serum albumin (BSA). Cells were then incubated with antiM. fermentans hyperimmune mouse serum, prepared as described elsewhere, ${ }^{34}$ for $40 \mathrm{~min}$ at room temperature. Then, the cells were washed three times with PBS, incubated with goat-anti-mouse conjugated AlexaFluor 488 for $40 \mathrm{~min}$ at room temperature and washed three times with PBS. The labeled cells were mounted on slides and examined by confocal laser-scanning microscopy (LSM410, Carl Zeiss, Jena, Germany).

\section{Measurement of TNF $\alpha$ secreted from U937}

At $24 \mathrm{~h}$ post infection of U937 cells with $M$. fermentans, as described above, the supernatants were collected by centrifugation $(500 \times g$ for $10 \mathrm{~min}$ ) and stored at $-20^{\circ} \mathrm{C}$. TNF $\alpha$ ELISA was performed according to the manufacturer's instructions. 


\section{Induction of apoptosis}

Infected U937 cells ( $24 \mathrm{~h}$ post infection) were counted, examined for viability by the trypan blue exclusion dye, centrifuged at $500 \times g$ for $10 \mathrm{~min}$, and transferred to a new culture medium at a final concentration of $4 \times 10^{5} \mathrm{cell} / \mathrm{s} / \mathrm{ml}$. The cells were divided in 24-well sterile plates (Corning, Corning, NY), and apoptosis was induced by TNF $\alpha$ at a concentration of $20 \mathrm{ng} / \mathrm{ml}$.

\section{Measurement of apoptosis}

Two different techniques were used: (1) AO-EB staining, an exclusion dye method, enables the differentiation between live, early-apoptotic, lateapoptotic and necrotic cells. ${ }^{18}$ At $8 \mathrm{~h}$ post induction of apoptosis by TNF $\alpha$, infected and noninfected cells $\left(4 \times 10^{5}\right)$ were collected, centrifuged at $500 \times g$ for $10 \mathrm{~min}$, and resuspended in $100 \mu \mathrm{l} \mathrm{PBS}$. Samples of $25 \mu \mathrm{l}$ from each culture were stained with AO-EB (final concentrations $1 \mu \mathrm{g} / \mathrm{ml}$ for each $\mathrm{AO}$ and $\mathrm{EB}$ ), and observed under a fluorescence microscope. At least 200 cells were randomly counted in each sample (in duplicates), and the percentage of apoptotic cells was calculated; (2) Annexin-V-FITC-PI staining, ${ }^{35}$ which detects the exposure of phosphatidylserine (PS) to the external leaflet of the plasma membrane in early apoptosis, enables to differentiate between live, early apoptotic and dead cells (it does not differentiate between late apoptotic and necrotic cells). ${ }^{36}$ At $4 \mathrm{~h}$ post induction of apoptosis by TNF $\alpha$, infected and noninfected cells $\left(2 \times 10^{5}\right)$ were washed with PBS, centrifuged and resuspended in $400 \mu \mathrm{l}$ of a binding buffer (10 mM HEPES/ $\mathrm{NaOH}, 140 \mathrm{mM} \mathrm{NaCl}, 2.5 \mathrm{mM} \mathrm{CaCl}_{2}, \mathrm{pH}$ 7.4). Annexin-V-FITC ( $5 \mu \mathrm{l} ; 10 \mu \mathrm{g} / \mathrm{ml})$ was added to a sample of $195 \mu \mathrm{l}$ of cell suspension, mixed, incubated for $10 \mathrm{~min}$ at room temperature in the dark, washed with PBS and resuspended in $190 \mu \mathrm{l}$ of binding buffer containing $10 \mu \mathrm{l}$ of $\mathrm{PI}(1 \mu \mathrm{g} / \mathrm{ml})$. The double-stained cells were analyzed by the FACS, within $10 \mathrm{~min}$ (10000 cells/sample).

In all measurements of apoptosis, we determined the percent of cells that underwent apoptosis by $\operatorname{TNF} \alpha$, by subtracting the percent of spontaneous apoptosis (unstimulated cells) from the total apoptosis (stimulated cells).

\section{Measurement of mitochondrial inner transmembrane potential $\left(\Delta \Psi_{m}\right)$}

At $2 \mathrm{~h}$ post induction of apoptosis by TNF $\alpha$, a total of $8 \times 10^{5}$ infected and noninfected cells were washed with PBS and resuspended in $990 \mu \mathrm{l}$ of PBS containing $10 \mu \mathrm{l}$ of $\mathrm{DiOC}_{6}$ (3) (final concentration $40 \mathrm{nM}$ ). Cells were mixed, incubated for $30 \mathrm{~min}$ at $37^{\circ} \mathrm{C}$ in the dark, and kept on ice until analyzed by the FACS within $10 \mathrm{~min}$ (10000 cells per sample). Cells with low $\mathrm{DiOC}_{6}(3)$ fluorescence represent cells with permeabilized mitochondria. A positive control, comprising $8 \times 10^{5}$ cells with $5 \mathrm{mM}$ of $\mathrm{mCiCCP}$, a mitochondrial uncoupler and a known reducer of $\Delta \Psi_{\mathrm{m}}{ }^{37}$, was incubated for $30 \mathrm{~min}$ at $37^{\circ} \mathrm{C}$ prior to the addition of $\mathrm{DiOC}_{6}(3)$.

\section{Measurement of protease activity of caspase-8}

At $4 \mathrm{~h}$ post induction of apoptosis by TNF $\alpha$, a total of $1.6 \times 10^{6}$ infected and noninfected cells were washed with PBS, resuspended in $80 \mu \mathrm{l}$ of icecold cell lysis buffer (50 mM HEPES, $1 \mathrm{mM}$ DTT, $0.1 \mathrm{mM}$ EDTA, $0.1 \%$ CHAPS, $0.1 \%$ Tween20, pH 7.4), and incubated for $5 \mathrm{~min}$ on ice. The resulting cell lysates were centrifuged at $13000 \times g$ for $10 \mathrm{~min}$ at $4^{\circ} \mathrm{C}$ and the supernatant (cytosolic fraction) was kept at $-70^{\circ} \mathrm{C}$ until analyzed. The test was performed according to the manufacturer's protocol (Calbiochem). Briefly, a sample of $15 \mu \mathrm{l}$ of each cell lysate was added to a well of a microtiter plate (Corning), containing $75 \mu$ of assay buffer $(100 \mathrm{mM}$ $\mathrm{NaCl}, 50 \mathrm{mM}$ HEPES, $10 \mathrm{mM}$ DTT, $1 \mathrm{mM}$ EDTA, 0.1\% CHAPS, $10 \%$ glycerol, $\mathrm{pH}$ 7.4). The positive control in this assay was a recombinant human caspase-8. To validate the caspase- 8 activity in the lysate, a negative control for each sample was analyzed. This control was an identical lysate sample to which $20 \mu$ lo Granzyme B Inhibitor II (Ac-IETD$\mathrm{CHO}$ ), final concentration $50 \mathrm{ng} / \mathrm{ml}$, was added. The plate was incubated at $37^{\circ} \mathrm{C}$ for $10 \mathrm{~min}$. Then, the reaction was initiated by adding $10 \mu \mathrm{l}$ of Granzyme B Substrate I, Colorimetric (Ac-IETD-pNA), final concentration $200 \mathrm{mM}$, and the change in absorbance was monitored at $405 \mathrm{~nm}$ for $2 \mathrm{~h}$, at 10 -min intervals.

Protein concentration of all lysates was determined by using the BioRad protein assay kit (Richmond, CA, USA), and protease activity of caspase-8 was calculated as a specific activity ( $\mathrm{pmol} / \mathrm{min} / \mu \mathrm{g}$ protein).

\section{Statistical analysis}

The statistical significance of differences between groups was performed by analysis of variance ANOVA: single factor, given in $P$-value. $P$-values of $<0.05$ were considered statistically significant; $P$-values of $<0.01$ were considered highly significant.

\section{Acknowledgements}

This work was partially supported by a grant from the Chief Scientist of the Israeli Ministry of Health (No. 4783, SH and JH), and partially by a grant from the Department of Research and Development of Ben-Gurion University of the Negev, Beer-Sheva, Israel (SH and JH). MG is a PhD student supported by the Kreitman Foundation, Ben-Gurion University of the Negev, Beer-Sheva, Israel. We thank Dr Mark Tarshis from the School of Medicine, The Hebrew University of Jerusalem, Israel, for his guidance and help with the confocal microscopy. We thank Sharon LeiboviciHorowitz for her excellent editing of this manuscript.

\section{References}

1. Razin S, Yogev D and Naot Y (1998) Molecular biology and pathogenicity of mycoplasmas. Microbiol. Mol. Biol. Rev. 62: 1094-1156

2. Brenner C, Wroblewski H, Le Henaff M, Montagnier L and Blanchard A (1997) Spiralin, a mycoplasmal membrane lipoprotein, induces T-cell-independent Bcell blastogenesis and secretion of proinflammatory cytokines. Infect. Immun. 65: 4322-4329

3. Marie C, Roman-Roman S and Rawadi G (1999) Involvement of mitogenactivated protein kinase pathways in interleukin-8 production by human monocytes and polymorphonuclear cells stimulated with lipopolysaccharide or Mycoplasma fermentans membrane lipoproteins. Infect. Immun. 67: 688-693

4. Muhlradt PF, Quentmeier $H$ and Schmitt $E$ (1991) Involvement of interleukin-1 (IL-1), IL-6, IL-2, and IL-4 in generation of cytolytic T cells from thymocytes stimulated by a Mycoplasma fermentans-derived product. Infect. Immun. 59: 3962-3968

5. Rawadi G, Roman-Roman S, Castedo M, Dutilleul V, Susin S and Marchetti P et al. (1996) Effects of Mycoplasma fermentans on the myelomonocytic lineage. Different molecular entities with cytokine-inducing and cytocidal potential. J. Immunol. 156: 670-678

6. Reyes L, Davidson MK, Thomas LC and Davis JK (1999) Effects of Mycoplasma fermentans incognitus on differentiation of THP-1 cells. Infect. Immun. 67: 3188-3192

7. Schaeverbeke $T$, Renaudin $H$, Clerc $M$, Lequen L, Vernhes JP and De Barbeyrac B et al. (1997) Systematic detection of mycoplasmas by culture and polymerase chain reaction (PCR) procedures in 209 synovial fluid samples. $\mathrm{Br}$. J. Rheumatol. 36: 310-314 
8. Firestein GS, Yeo M and Zvaifler NJ (1995) Apoptosis in rheumatoid arthritis synovium. J. Clin. Invest. 96: 1631-1638

9. Horowitz S, Evinson B, Borer A and Horowitz J (2000) Mycoplasma fermentans in rheumatoid arthritis and other inflammatory arthritides. J. Rheumatol. 27: 2747-2753

10. Nishioka K, Hasunuma T, Kato T, Sumida T and Kobata T (1998) Apoptosis in rheumatoid arthritis: a novel pathway in the regulation of synovial tissue. Arthritis Rheum. 41: 1-9

11. Perlman H, Pagliari LJ and Volin MV (2001) Regulation of apoptosis and cell cycle activity in rheumatoid arthritis. Curr. Mol. Med. 1: 597-608

12. Cutolo M, Barone A, Accardo S, Setti M and Villaggio B (1998) Effect of cyclosporin on apoptosis in human cultured monocytic THP-1 cells and synovial macrophages. Clin. Exp. Rheumatol. 16: 417-422

13. Ashkenazi A and Dixit VM (1998) Death receptors: signaling and modulation. Science 281: 1305-1308

14. Thornberry NA and Lazebnik Y (1998) Caspases: enemies within. Science 281: 1312-1316

15. Hall RE, Agarwal S and Kestler DP (2000) Induction of leukemia cell differentiation and apoptosis by recombinant P48, a modulin derived from Mycoplasma fermentans. Biochem. Biophys. Res. Commun. 269: 284-289

16. Paddenberg R, Weber A, Wulf S and Mannherz HG (1998) Mycoplasma nucleases able to induce internucleosomal DNA degradation in cultured cells possess many characteristics of eukaryotic apoptotic nucleases. Cell Death Differ. 5: 517-528

17. Feng SH, Tsai S, Rodriguez J and Lo SC (1999) Mycoplasmal infections prevent apoptosis and induce malignant transformation of interleukin-3dependent 32D hematopoietic cells. Mol. Cell. Biol. 19: 7995-8002

18. Renvoize C, Biola A, Pallardy M and Breard J (1998) Apoptosis: identification of dying cells. Cell Biol. Toxicol. 14: 111-120

19. Bradham CA, Qian T, Streetz K, Trautwein C, Brenner DA and Lemasters JJ (1998) The mitochondrial permeability transition is required for tumor necrosis factor alpha-mediated apoptosis and cytochrome $c$ release. Mol. Cell. Biol. 18: 6353-6364

20. Green DR and Reed JC (1998) Mitochondria and apoptosis. Science 281: 1309-1312

21. Taylor-Robinson D, Sarathchandra P and Furr PM (1993) Mycoplasma fermentans-HeLa cell interactions. Clin. Infect. Dis. 17 (Suppl 1): S302-S304

22. Ben-Menachem G, Mousa A, Brenner T, Pinto F, Zahringer U and Rottem S (2001) Choline deficiency induced by Mycoplasma fermentans enhances apoptosis of rat astrocytes. FEMS Microbiol. Lett. 201: 157-162

23. Airenne S, Surcel HM, Tuukkanen J, Leinonen M and Saikku P (2002) Chlamydia pneumoniae inhibits apoptosis in human epithelial and monocyte cell lines. Scand. J. Immunol. 55: 390-398
24. Rajalingam K, Al-Younes $H$, Muller A, Meyer TF, Szczepek AJ and Rudel T (2001) Epithelial cells infected with Chlamydophila pneumoniae (Chlamydia pneumoniae) are resistant to apoptosis. Infect. Immun. 69: 7880-7888

25. Ray RB, Meyer K, Steele R, Shrivastava A, Aggarwal BB and Ray R (1998) Inhibition of tumor necrosis factor (TNF-alpha)-mediated apoptosis by hepatitis C virus core protein. J. Biol. Chem. 273: 2256-2259

26. James ER and Green DR (2002) Infection and the origins of apoptosis. Cell Death Differ. 9: 355-357

27. Adams JM and Cory S (2001) Life-or-death decisions by the Bcl-2 protein family. Trends Biochem. Sci. 26: 61-66

28. Vander Heiden MG and Thompson CB (1999) Bcl-2 proteins: regulators of apoptosis or of mitochondrial homeostasis? Nat. Cell Biol. 1: E209-E216

29. Wang CY, Mayo MW, Korneluk RG, Goeddel DV and Baldwin Jr AS (1998) NFkappaB antiapoptosis: induction of TRAF1 and TRAF2 and c-IAP1 and c-IAP2 to suppress caspase-8 activation. Science 281: 1680-1683

30. Sacht G, Marten A, Deiters U, Sussmuth R, Jung G and Wingender E et al. (1998) Activation of nuclear factor-kappaB in macrophages by mycoplasmal lipopeptides. Eur. J. Immunol. 28: 4207-4212

31. Stolzenberg I, Wulf S, Mannherz HG and Paddenberg R (2000) Different sublines of Jurkat cells respond with varying susceptibility of internucleosoma DNA degradation to different mediators of apoptosis. Cell Tissue Res. 301: 273-282

32. Tully J 1983 General cultivation techniques for Mycoplasmas and Spiroplasmas In Methods in Mycoplasmology Razin S and Tully J (eds) (New York, NY: Academic Press Inc) pp. 99-102

33. Kenny G 1980 Mycoplasma In Manual of Clinical Microbiology 3rd edn, Lennette EH, Balows A, Hausler Jr WJ and Truant JP (eds) (Washington, DC: American Society for Microbiology) pp. 365-370

34. Horowitz S, Horowitz J, Hou L, Fuchs E, Rager-Zisman B and Jacobs E et al. (1998) Antibodies to Mycoplasma fermentans in HIV-positive heterosexual patients: seroprevalence and association with AIDS. J. Infect. 36: $79-84$

35. Vermes I, Haanen C, Steffens-Nakken H and Reutelingsperger C (1995) A novel assay for apoptosis. Flow cytometric detection of phosphatidylserine expression on early apoptotic cells using fluorescein labelled Annexin V. J. Immunol. Methods 184: 39-51

36. Bossy-Wetzel E and Green DR (2000) Detection of apoptosis by annexin V labeling. Methods Enzymol. 322: 15-18

37. Zamzami N, Marchetti P, Castedo M, Zanin C, Vayssiere JL and Petit PX et al. (1995) Reduction in mitochondrial potential constitutes an early irreversible step of programmed lymphocyte death in vivo. J. Exp. Med. 181: $1661-1672$ 